\title{
Synthesis and Characterization of Hybrid-Magnetic Nanoparticles and Their Application for Removal of Arsenic from Groundwater
}

\author{
Marta A. Bavio and Adriana G. Lista \\ FIA Laboratory, Analytical Chemistry Section, INQUISUR (UNS-CONICET), Avenue Alem 1253, B8000CPB Bahía Blanca, \\ Buenos Aires, Argentina \\ Correspondence should be addressed to Adriana G. Lista; alista@criba.edu.ar
}

Received 5 August 2013; Accepted 28 August 2013

Academic Editors: C. Chen and T. Kojima

Copyright ( 2013 M. A. Bavio and A. G. Lista. This is an open access article distributed under the Creative Commons Attribution License, which permits unrestricted use, distribution, and reproduction in any medium, provided the original work is properly cited.

Multiwall carbon nanotubes (MWCNTs) were oxidized with different agents and a characterization study was carried out. Then, hybrid-magnetic nanoparticles (HMNPs) were synthesized as iron oxide supported on the selected multiwalled carbon nanotubes (MWCNTs- $\mathrm{Fe}_{3} \mathrm{O}_{4}$ ) obtained from MWCNTs oxidized with $\mathrm{HNO}_{3}$. The HMNPs characterization revealed the presence of iron oxide as magnetite onto the MWCNTs surfaces. These HMNPs were used for arsenic removal from groundwater. The adsorption process variables were optimized (concentration of NPs, contact time, and $\mathrm{pH}$ ), and these systems could remove $39.93 \mathrm{mg}$ As/g adsorbent. Therefore, these nanoparticles appear as a good alternative for removing arsenic from water samples.

\section{Introduction}

Arsenic is a toxic element and its presence in drinking water has caused the spread of endemic regional chronic hydroarsenicism (HACRE), evolving into more serious diseases like cancers, especially skin, lung, and liver cancer and lymphoma. The routes of exposure to humans are basically throughout the air, drinking water, or food [1]. High arsenic concentration can be found in drinking well water in many countries such as New Zealand, Romania, and Argentina. It is well known that new water sources are necessary, and the search is focused mostly on underground. Unfortunately, deterioration of this kind of water sources is observed. As an example, it can be mentioned the areas of La Pampa (Argentina), where it can be found aquifers with high contents in salt and arsenic (total dissolved solids greater than $1,400 \mathrm{ppm}$ and 600-1200 ppb, resp.) [2]. Since 2007, the World Health Organization recommends a maximum concentration level of $10 \mu \mathrm{g}$ total arsenic $\mathrm{L}^{-1}$ [3] for drinking water (in 2004 the maximum was $50 \mu \mathrm{g} \mathrm{L}^{-1}$ ).

The arsenic concentration in groundwater is usually controlled by natural geochemical processes, where adsorptiondesorption reactions of As species on mineral surfaces play a key role. Adsorption-desorption processes are also important to develop water purification technologies, with the aim of removing As from water [4-7]. Arsenate adsorption has been studied using a variety of adsorbents. Most of the studies were performed using $\mathrm{Fe}(\mathrm{III})$ (hydr)oxides, which show highly selective adsorption capacities [8-16]. There is also considerable information about arsenate adsorption on phyllosilicates due to their high surface area. However, arsenate adsorption on these materials is lower than on minerals containing iron [17-20].

Magnetic carbon nanotubes composites are hybrids of magnetite $\left(\mathrm{Fe}_{3} \mathrm{O}_{4}\right)$ and/or maghemite $\left(\gamma\right.$ - $\left.\mathrm{Fe}_{2} \mathrm{O}_{3}\right)$ with singlewalled (SWCNTs) or multiwalled carbon nanotubes (MWCNTs). These composites combine the unique optical, electri$\mathrm{cal}$, and mechanical properties of carbon nanotubes (CNTs) and the paramagnetic or ferromagnetic properties of hybridmagnetic nanoparticles (HMNPs) at room temperature. Such advantages have enabled their use as tips for magnetic force microscopes, separators in wastewater treatment, biosensors, drug delivery systems, and biomanipulators [21-24]. Magnetic CNTs can be prepared in different ways. A method involving the synthesis in situ of HMNPs onto the surface 
of CNTs holds much promise for large-scale synthesis [2528]. Tan et al. [29] prepared magnetic CNTs by dispersing nanotubes in iron pentacarbonyl for their vacuum thermolysis and oxidation. Another method for in situ preparation of MNP-CNT composites involves decomposing ferrocene at a high temperature $\left(350-500^{\circ} \mathrm{C}\right)$ onto previously purified CNTs. Chemical precipitation has also been used for in situ decoration of CNTs; the nanotubes are first oxidized in order to avoid breaking the tubes, and the process can be performed at fairly low temperatures [30]. Huiqun et al. [31] used chemical precipitation to decorate carbon nanotubes with iron oxide particles; the resulting hybrid particles spanned a broad range of sizes [32].

The aims of this work were to obtain magnetic nanoparticles and to carry out their characterization in order to use them as arsenic sorbent. Therefore, to synthesize the magnetic nanoparticles, a reaction onto the CNT surfaces was carried out by using a simple one step at high temperature. The precursor (iron chloride) and MWCNTs were homogenized in ethyleneglycol [33]. Although a high temperature was needed for efficient decoration, the reaction was relatively selective and sensitive. The product was characterized by using different techniques, and the obtained HMNPs were used in the targeted analysis for removing arsenic from contaminated groundwater.

\section{Experimental}

2.1. Apparatus. An Agilent HP 8453A UV-VIS spectrophotometer, with linear photodiode arrangement and a glass cell (1 cm of optic path), was used to quantify arsenic. Also a Perkin Elmer Optima 7000 atomic emission spectrophotometer with inductively coupled plasma was used.

The MWCNTs and HMNPs characterization was carried out using a Nicolet FTIR spectrophotometer, model Nexus 470; a scanning electronic microscope (SEM) LEO EVO 40 XVP model. Malvern Zetasizer Nano ZS90 was used for the zeta potential measurements. Powder X-ray diffraction was measured with a Phillips PW1710 diffractometer between $10^{\circ}$ and $70^{\circ} 2 \theta$ using $\mathrm{CuK} \alpha$ radiation.

An ultrasonic bath Cole Palmer, a Gilson Minipuls 3 peristaltic, a $\mathrm{pH}$-meter $\mathrm{pH} / \mathrm{ISE}$ Meter Orion, and an analytical balance Ohaus AS120E were also used. A neodymium rare earth metal magnet disk of approximately $117,7 \mathrm{~N}$ in strength was applied for HMNPs separation.

2.2. Reagents and Solutions. All solutions were prepared using analytical reagent-grade and ultrapure water (18.0 $\mathrm{m} \Omega \mathrm{cm}^{-1}$, Milli-Q).

A $100 \mu \mathrm{mol} \mathrm{L}{ }^{-1}$ stock solution of arsenate was prepared by dissolving $0.0156 \mathrm{~g}$ of $\mathrm{Na}_{2} \mathrm{HAsO}_{4} \cdot 7 \mathrm{H}_{2} \mathrm{O}$ (Merck, Argentina) in water to make up to $50 \mathrm{~mL}$. The standard solutions were daily prepared by diluting the stock solution with water. The color reagent for the arsenate spectrophotometric determination was prepared according to Tsang et al. [34]. A solution of ascorbic acid $\left(0.57 \mathrm{~mol} \mathrm{~L}^{-1}\right)$ was prepared by dissolving $1.08 \mathrm{~g}$ ascorbic acid (Cicarelli, Argentina) in water and making up to $10 \mathrm{~mL}$. This solution must be prepared and kept at $4^{\circ} \mathrm{C}$. In these conditions, the solution can be used for 7 days.

Buffer solution of $\mathrm{pH} 2$ was prepared by mixing $0.16075 \mathrm{~g}$ of citric acid (Cicarelli, Argentina), $0.0895 \mathrm{~g}$ of sodium chloride (Cicarelli, Argentina), and $0.205 \mathrm{~mL}$ of $1 \mathrm{~mol} \mathrm{~L}^{-1}$ hydrochloric acid (Merck, Argentina).

MWCNTs (>95\% purity) were purchased from Bayer, Spain: inner diameter of $13-16 \mathrm{~nm}$ and $1-10 \mu \mathrm{m}$ of length.

2.3. Purification and Functionalization of MWCNTs. A thermal purification step of the MWCNTs was carried out at $350^{\circ} \mathrm{C}$ in a flask for $30 \mathrm{~min}$. Then, these nanotubes were treated with $\mathrm{HNO}_{3} 4 \mathrm{~mol} \mathrm{~L}-1$ for $2 \mathrm{~h}$ at room temperature to remove residual catalyst metals. They were washed with ultrapure water and dried at $110^{\circ} \mathrm{C}$ for $24 \mathrm{~h}$.

In a second step, they were functionalized with different oxidants as it is indicated below.

(i) Refluxing with concentrated $\mathrm{HNO}_{3}$ at $150^{\circ} \mathrm{C}$ for $2 \mathrm{~h}$ [35].

(ii) Heating with $0.5 \mathrm{~mol} \mathrm{~L}^{-1} \mathrm{KMnO}_{4}$ at $80^{\circ} \mathrm{C}$ for $3 \mathrm{~h} \mathrm{[36].}$

(iii) Heating with a solution containing $\mathrm{HNO}_{3}$ and $\mathrm{HSO}_{4}$ in a ratio $1: 3$, at $85^{\circ} \mathrm{C}$ for $3 \mathrm{~h} \mathrm{[37].}$

(iv) Suspension with a solution of $70 \% \mathrm{NaOCl}$, stirring for $20 \mathrm{~min}$ and then heating at $85^{\circ} \mathrm{C}$ for $3 \mathrm{~h} \mathrm{[38].}$

In all cases, the obtained MWCNTs were washed with ultrapure water and dried at $110^{\circ} \mathrm{C}$ for $24 \mathrm{~h}$. Then, they were characterized by IR spectroscopy and zeta potential measurements.

2.4. Hybrid-Magnetic Nanoparticles (HMNPs) Synthesis. The characterization of the oxidized MWCNTs indicated that those treated with $\mathrm{HNO}_{3}$ were the best for further modification with iron.

HMNPs were synthesized following a similar procedure described by Zhan et al. [39]. Briefly, an amount of $14 \mathrm{mg}$ of $\mathrm{FeCl}_{3} \cdot 6 \mathrm{H}_{2} \mathrm{O}$ and $1 \mathrm{mg}$ of the selected MWCNTs was suspended in $0.75 \mathrm{~mL}$ of ethyleneglycol in a glass vial. This solvent was used to provide monodispersed $\mathrm{Fe}_{3} \mathrm{O}_{4}$ nanoparticles. Then, $0.036 \mathrm{~g}$ sodium acetate was added and dissolved in order to get the electrostatic stabilization and to prevent particles agglomeration. This solution was kept at room temperature for $30 \mathrm{~min}$. Then, the glass vial was placed in an airtight steel container and heated in an oven at $200^{\circ} \mathrm{C}$ for $16 \mathrm{~h}$. After cooling to room temperature, the synthetic product was washed with $1 \mathrm{~mL}$ of water, and nanoparticles were recovered by applying a magnetic field with a magnetic disk placed on the outer wall of the glass vial. This cleanup procedure was repeated 5 times. The nanoparticles thus obtained can be stored in a dessicator until being used.

The general equations for the reaction are

$$
\begin{gathered}
\mathrm{Fe}^{2+}+2 \mathrm{Fe}^{3+}+8 \mathrm{OH}^{-}+\text {MWCNTs } \\
\longrightarrow \frac{\mathrm{MWCNTs}}{\mathrm{Fe}_{3} \mathrm{O}_{4}}+4 \mathrm{H}_{2} \mathrm{O}
\end{gathered}
$$




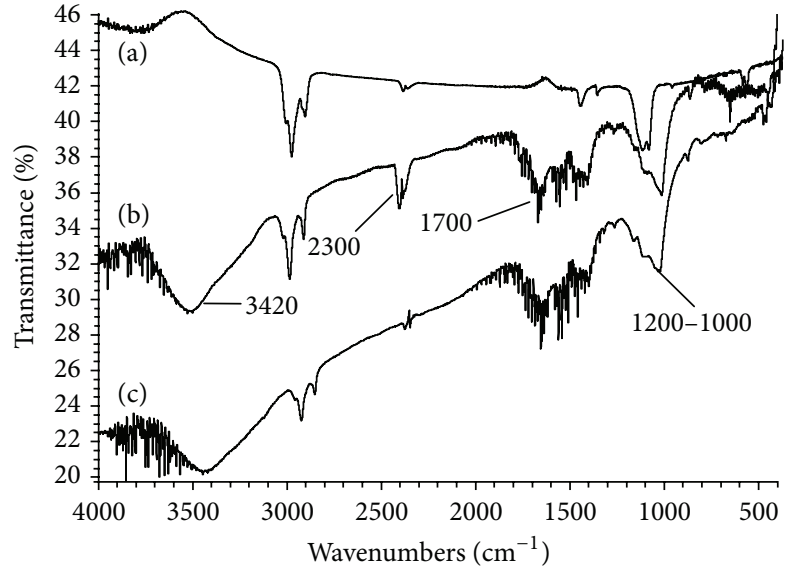

FIGURE 1: IR Spectra of purified and oxidized MWCNTs with (b) $\mathrm{HNO}_{3}$ and (c) $\mathrm{NaOCl}$.

2.5. As $(V)$ Adsorption Procedure. The obtained HMNPs were used to remove the $\mathrm{As}(\mathrm{V})$ from water samples. For this purpose, a suitable amount of the nanoparticles was placed in a glass tube with a solution containing a determined concentration of $\mathrm{As}(\mathrm{V})$. It was necessary to work at $\mathrm{pH} 2$ to improve the $\mathrm{As}(\mathrm{V})$ adsorption on the HMNPs. The mixture was sonicated during 3 hours and then the hybrid-magnetic nanoparticles were isolated by using a magnetic field. In this way, the removal of the magnetic nanoparticles from solution was more selective and efficient (and often much faster) than centrifugation or filtration [40].

The concentration of $\mathrm{As}(\mathrm{V})$ in the liquid phase was spectrophotometrically determined following the modified method based on the use of molybdenum blue [34].

\section{Results and Discussion}

\subsection{Characterization of Oxidized MWCNTs}

3.1.1. IR Spectroscopy. Figure 1 shows the IR spectra of purified and oxidized MWCNTs with the different oxidants. The spectrum of purified MWCNTs only exhibits peaks of $-\mathrm{CH}_{2}$ group because of the aromatic structure of nanotubes. On the other hand, the MWCNTs treated with $\mathrm{NaOCl}$ and $\mathrm{HNO}_{3}$ present four peaks at $\sim 3420,2300,1700$, and $1200-1000 \mathrm{~cm}^{-1}$. These peaks correspond to the tension bands of the hydroxyl $(-\mathrm{OH})$, carboxyl $(-\mathrm{COO}-)$, carbonyl $(-\mathrm{C}=\mathrm{O})$, and $\mathrm{C}-\mathrm{O}$ bond, respectively. This fact confirms the chemical modification on the surface of nanotubes with acid group. The spectra of the nanotubes oxidized with $\mathrm{KMnO}_{4}$ and $3 \mathrm{~N}+1 \mathrm{~S}$ did not present differences from the purified nanotubes.

3.1.2. Zeta Potential. The zeta potential is the electrical potential that exists in the liquid/solid interface. The development of electrical charge on the particle surface can affect the distribution of ions in a neighboring interfacial region, causing an increase in concentration of counterions near the surface. Figure 2 shows the zeta potentials of purified and functionalized MWCNTs with different oxidants versus $\mathrm{pH}$. As the $\mathrm{pH}$ increased, the surface charge of MWCNTs

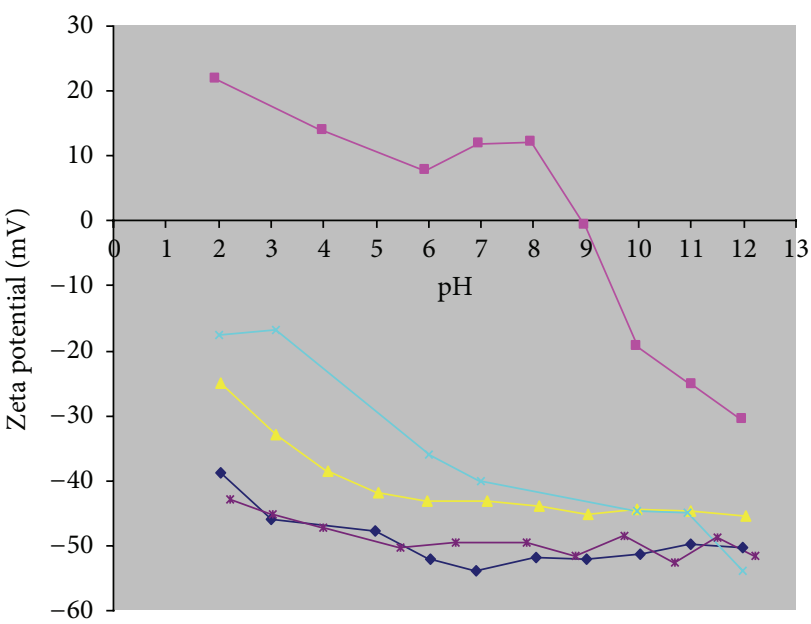

FIGURE 2: Zeta potentials of purified ( $\mathbf{\square})$ and oxidized MWCNTs with $\mathrm{HNO}_{3}(\downarrow) ; 3 \mathrm{~N}+1 \mathrm{~S}(\mathrm{X}) ; \mathrm{KMnO}_{4}(\mathbf{\Delta}) ; \mathrm{NaOCl}(*)$, under various $\mathrm{pH}$.

becomes more negative because there are more acid groups that lose protons. Where the zeta potential curve versus $\mathrm{pH}$ crosses the $x$-axis, isoelectric point (IEP) is obtained. When the $\mathrm{pH}$ is lower than IEP, the acidic solution donates more protons than the surface. Above IEP, the reverse situation takes place.

For Zeta potential measurements, $25 \mathrm{mg}$ of MWCNTs is dispersed in $50 \mathrm{~mL}$ of ultrapure water and sonicated during $20 \mathrm{~min}$. Before each measurement, the $\mathrm{pH}$ is adjusted between 2 and 12 with $0.1 \mathrm{M} \mathrm{HCl}$ or $\mathrm{NaOH}$ solutions. The ionic strength in this study is kept constant using a $0.02 \mathrm{~mol} \mathrm{~L}^{-1} \mathrm{NaCl}$ solution. As can be seen in Figure 2, the zeta potential of purified MWCNTs is positive at $\mathrm{pHs}$ below the IEP and negative above this point. On the other hand, all the oxidized MWCNTs have negative zeta potential at all the tested pHs, and those modified with $\mathrm{HNO}_{3}$ and $\mathrm{NaOCl}$ show the lowest values. This indicates that more acidic groups were added to the surface, and then further analyses were carried out using those that were oxidized with $\mathrm{HNO}_{3}$.

\subsubsection{SEM Images of Purified and Oxidized MWCNTs with} $H_{3}$. Figures 3(a) and 3(b) show the SEM images at different scales of the purified and oxidized MWCNTs, respectively. The first one shows large and curve nanotubes that are much agglomerated because of the Van der Walls forces. In the second one, it was observed that the agglomeration is lower, and the nanotubes are shorter because of the drastic acid treatment. A break in the defects of the tube is produced, and the ends of nanotubes are opened because there is more tension in the cycles of five atoms of carbon located there.

\subsection{Characterization of HMNPs}

3.2.1. IR Spectroscopy, X-Ray Diffraction, and Zeta Potential. Figure 4 shows IR spectra of the HMNPs. Peaks corresponding to the functional groups added after the chemical treatment are observed, and one new peak is identified at 

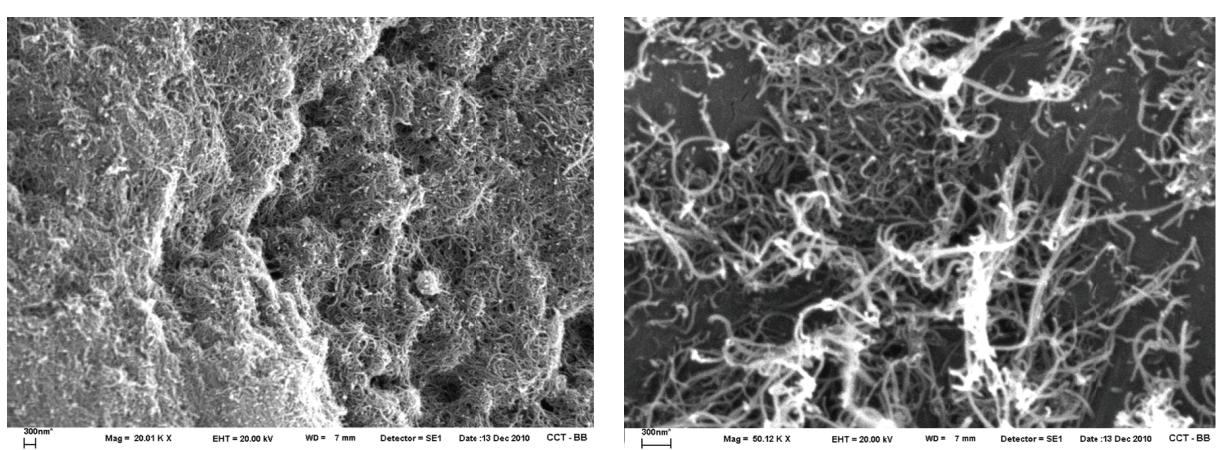

(a)
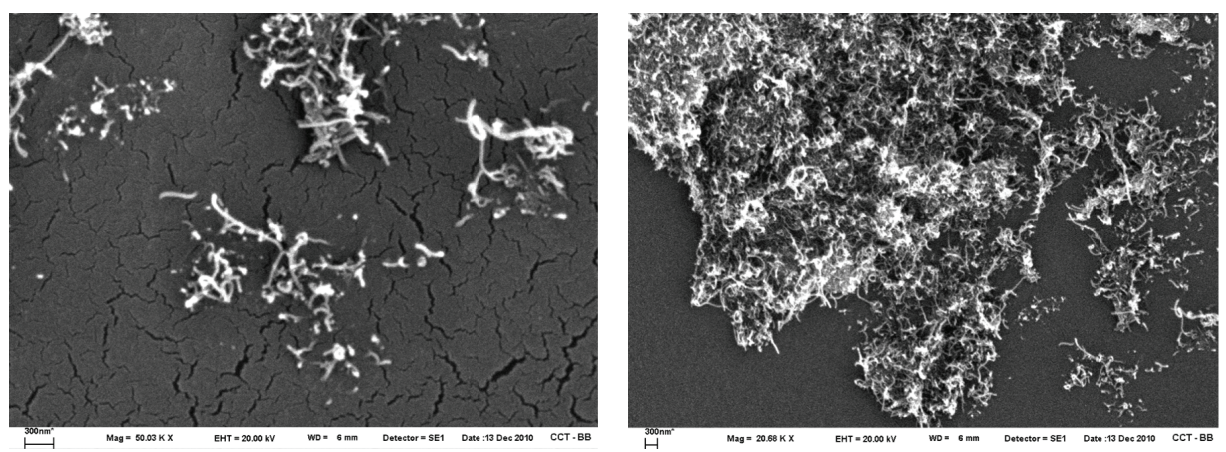

(b)

FIGURE 3: SEM images of MWCNTs (a) purified at 20000x and 50000x and (b) oxidized with $\mathrm{HNO}_{3}$ at 20000x and 50000x. The scale in all figures is $300 \mathrm{~nm}$.

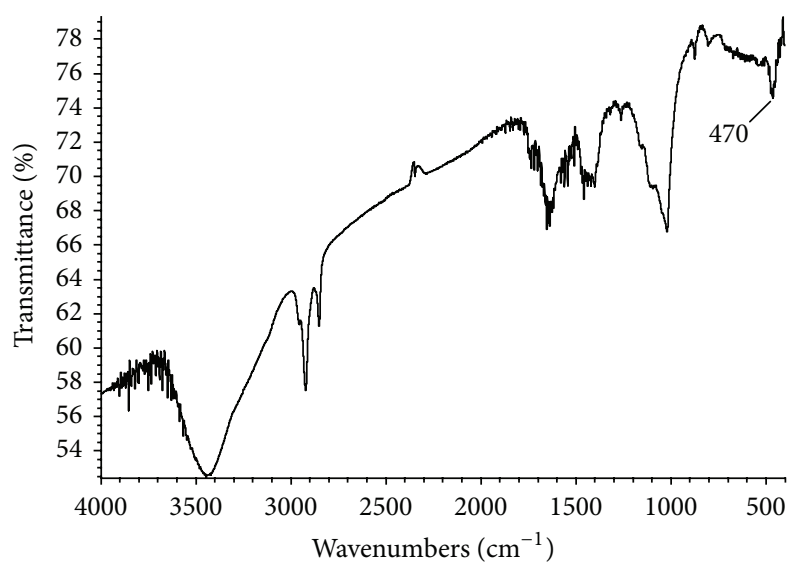

FIGURE 4: IR Spectra of HMNPs: oxidized MWCNTs decorated with $\mathrm{Fe}_{3} \mathrm{O}_{4}$.

$470 \mathrm{~cm}^{-1}$ due to $\mathrm{Fe}-\mathrm{O}$ bond resulting from the modification with iron [41].

The zeta potential of the hybrid nanoparticles was positive at $\mathrm{pH}$ lower than 3.0 (i.e., the IEP) and negative at $\mathrm{pH}$ over this value. This change indicates the adsorption of the iron oxide on the MWCNTs surface. So, the best $\mathrm{pH}$ values for the adsorption of arsenate are below $\mathrm{pH} 3$, where the surface of the HMNPs is positive and, therefore, anions are more attracted.

It should be noted that the natural magnetite IEPs reported in the literature are between 5 and 6.8 [42], different to those obtained for the synthesized HMNPs. This fact is due to the magnitude of the negative zeta potential of the precursor MWCNTs.

The XRD patterns of MWCNTs oxidized with $\mathrm{HNO}_{3}$ and iron-decorated MWCNTs are given in Figures 5(a) and 5(b). In Figure 5(a), the peak at $2 \theta=26.2^{\circ}$ indicates the typical signal of carbon nanotubes or graphite structures. This peak is associated with the (002) diffraction of the hexagonal graphite structure in the carbon materials. Figure 5(b) shows that a new hybrid magnetic structure was synthesized and had the chemicals composition of $\mathrm{Fe}_{3} \mathrm{O}_{4}$ (magnetite). New peaks at $18.5^{\circ}, 30.3^{\circ}, 35.6^{\circ}, 43.1^{\circ}, 53.6^{\circ}$, and $57.0^{\circ}$ were observed. The positions match well with (111), (220), (311), (400), (422), and (511) planes of the standards XRD data of the cubical spinal crystal structure of magnetite. The principal peak of graphene structure at $26.2^{\circ} \mathrm{did}$ not appear probably because of the high ratio of magnetite composite with respect to carbon nanotubes. One peak that can be assigned to the graphene structure at $43.3^{\circ}$ is distinguished, corresponding to the (101) plane.

3.2.2. SEM Images of HMNPs. Figure 6, show the SEM images at different scales of the iron-decoratived MWCNTs. They show short and straight nanotubes with little clusters of iron oxide with a diameter of about $60 \mathrm{~nm}$.

All of these analyses indicate that iron, as magnetite, is adsorbed on the oxidized MWCNTs. So, the content of iron in HMNPs was determined. 


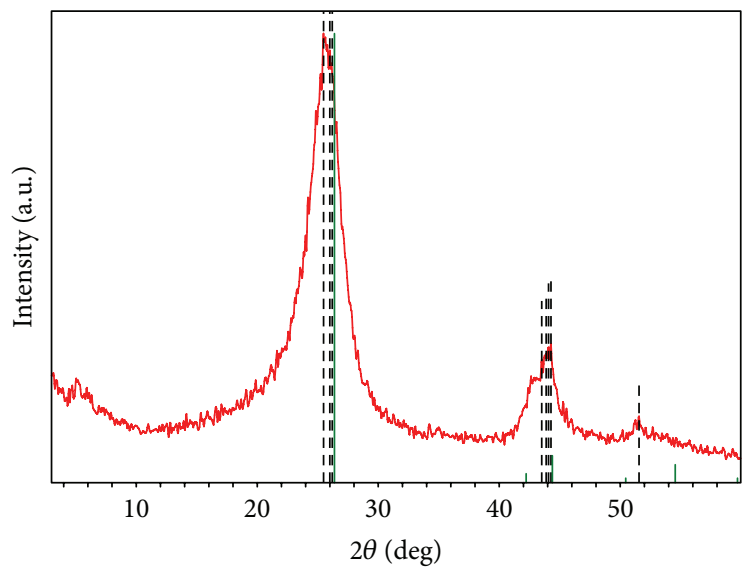

(a)

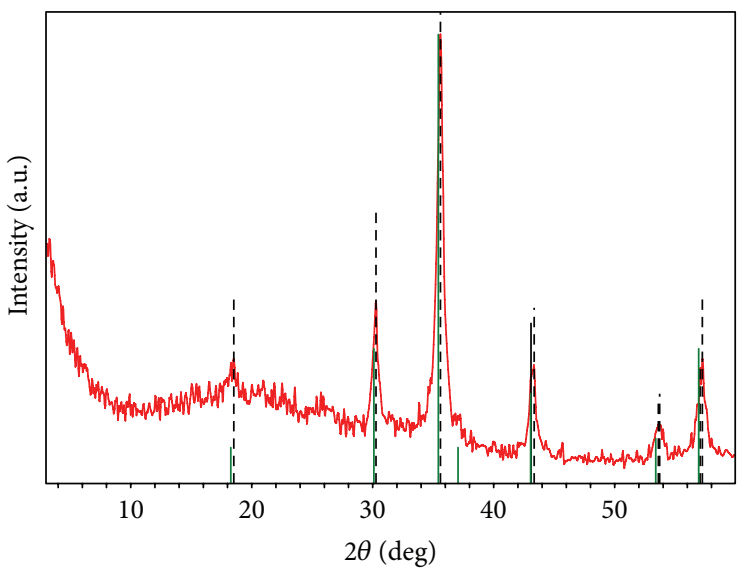

(b)

FIgURE 5: XRD patterns of (a) oxidized MWCNTs with $\mathrm{HNO}_{3}$ and (b) HMNPs.
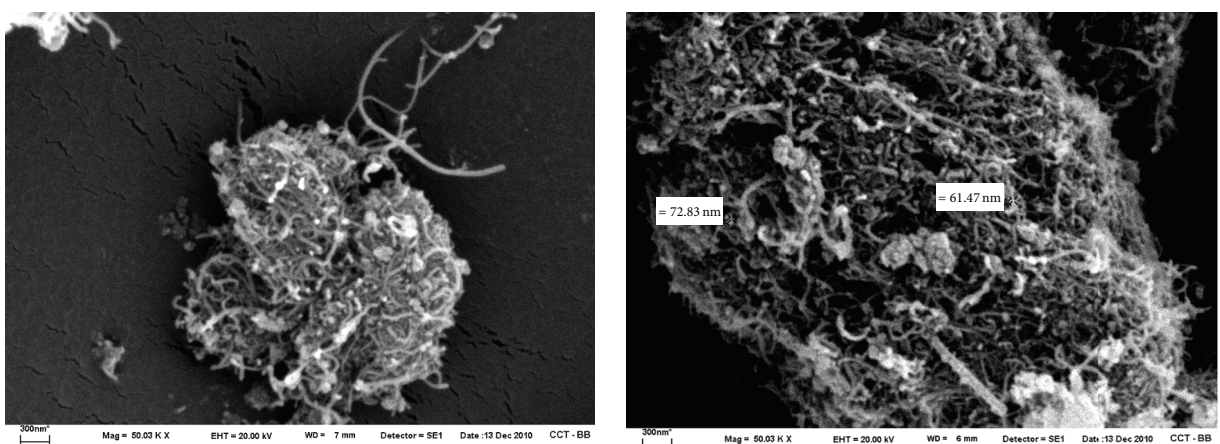

FIGURE 6: SEM images of HMNPs at 50000x. The scale in all figures is $300 \mathrm{~nm}$.

3.2.3. Content of Iron in HMNPs. The iron content of the studied solids was determined by extraction with $\mathrm{HCl}$ [43]. $50 \mathrm{mg}$ of solid was treated with $10 \mathrm{~mL}$ of concentrate $\mathrm{HCl}$ at $60-80^{\circ} \mathrm{C}$ during 1 hour. Then, the iron content in the separated supernatant was determined by using the spectrophotometric tiocianate method at $475 \mathrm{~nm} \mathrm{[44].} \mathrm{The}$ obtained result was $234.5 \mathrm{mg} \mathrm{Fe}^{+3} / \mathrm{g}$ of HMNPs, which means that $23.4 \%$ of the nanoparticles corresponds to iron.

3.3. As $(V)$ Adsorption Procedure Optimization. For this purpose, $\mathrm{pH}$, contact time, and amount of HMNPs were studied. It is well known that it is necessary to achieve the equilibrium of the adsorption process, and, for this, the contact time between the HMNPs and the analyte is crucial.

The $\mathrm{pH}$ is other critical variable because the HMNPs surficial charge and the behavior of the As species depend on it. Finally, the concentration of HMNPs dispersed in the solution must be adequate in order to have the maximum surface available for the interaction with the arsenate ions.

The optimization of the mentioned variables was carried out by the univariant way and using the calibration curve obtained with the modified molybdenum blue method. The linear range for the straight line $\left(y=0.0003 \mu \mathrm{g} \mathrm{L}{ }^{-1}\right.$ $\left.0.0018 ; R^{2}=0.998\right)$ was between 40 and $600 \mu \mathrm{g} \mathrm{As}(\mathrm{V}) \mathrm{L}^{-1}$.
A $600 \mu \mathrm{gL}^{-1}$ arsenic solution was used as initial concentration for the study of each variable, considering that the absorbance measurements were carried out on the supernatant solution after the adsorption procedure. The optimum value for each variable was selected considering the greatest difference between the As(V) concentration before and after the adsorption procedure.

The studied ranges for the variables and the optimal values for each one appear in Table 1.

Working under these conditions, a maximum of $53 \mathrm{mg}$ As $(\mathrm{V}) / \mathrm{g}$ of HMNPs can be removed from contaminated solutions. This value is lower than the result reached with akaganeita $(\beta-\mathrm{FeOOH})(120 \mathrm{mg} \mathrm{As} / \mathrm{g})[45]$. However, it is closer to the ones obtained with ferrihydrite $\left(5 \mathrm{Fe}_{2} \mathrm{O}_{3} \cdot 9 \mathrm{H}_{2} \mathrm{O}\right)$ and maghemite (i.e., 52 and $50 \mathrm{mg} \mathrm{As/g,} \mathrm{resp.)} \mathrm{[46,} \mathrm{47]} \mathrm{and}$ higher than the results obtained when zeolite dopped with $\mathrm{Fe}$ is used (35 mg As/g) [48].

3.4. Arsenic Determination in Real Samples. Two groundwater samples from different zones of the Bahía Blanca city were analysed. The determination of As in real samples was done by ICP. The analyses were carried out on samples with and without adsorption procedure using HMNPs, and the results are shown in Table 2. 
TABLE 1: Adsorption process: optimization of variables.

\begin{tabular}{lccc}
\hline & $\begin{array}{c}\text { Studied } \\
\text { range }\end{array}$ & $\begin{array}{c}\text { Selected } \\
\text { value }\end{array}$ & $\begin{array}{c}\text { mg As(V)/g } \\
\text { HMNPs }\end{array}$ \\
\hline Contact time (h) & $1-6$ & 3 & 32.70 \\
Amount of adsorbent (mg) & $1-7$ & 3.5 & 37.97 \\
$\mathrm{pH}$ & $2-7$ & 2 & 39.93 \\
\hline
\end{tabular}

TABLE 2: Analysis of real groundwater samples.

\begin{tabular}{lcc}
\hline Groundwater samples & Palihue & Patagonia \\
\hline Total As concentration founded $\left(\mu \mathrm{g} \cdot \mathrm{L}^{-1}\right)$ & & \\
Untreated sample & $37 \pm 0.5$ & $353 \pm 1.9$ \\
Treated sample* & $25.5 \pm 0.7$ & $165.5 \pm 2.1$ \\
Total As adsorbed (mg As/g HMNPs) & 31.00 & 53.11 \\
\hline
\end{tabular}

${ }^{*}$ Average of three replicates.

As can be seen, the amount of adsorbed arsenic is different in both samples. When the concentration is higher, the percentage of adsorbed arsenic is higher too. This fact is consistent with previous publications, which indicate that the adsorption of As on natural magnetic nanomaterials decreases when the initial concentration of As in the sample is lower [49].

It is clear that the adsorption process occurs in real samples with both species of $\mathrm{As}(\mathrm{V})$ and As(III). It should be remembered that the $\mathrm{As}(\mathrm{V})$ binds more strongly to $\mathrm{Fe}$ or Mn oxides, compared with the species of As(III). Also, the adsorptive affinity for $\mathrm{As}(\mathrm{V})$ is higher at acid $\mathrm{pH}$, and for As(III) alkaline conditions are more favourable [50].

\section{Conclusions}

The functionalization of multiwall carbon nanotubes was verified with different characterization techniques. Those treated with $\mathrm{HNO}_{3}$ were selected as substrate for the preparation of HMNPs. The modification of this MWCNTs with Fe (III) salt resulted in an hybrid nanoparticle (combination of MWCNTs and iron oxide nano particles) with a high capability for arsenic adsorption. On the other hand, the magnetic behavior of these nanoparticles makes possible their separation from the sample solution after the treatment.

Even though the synthesized HMNPs adsorb less than some natural adsorbents as akaganeite, the obtained results make it possible to conclude that this nanotechnology is an original and potential solution for arsenic removal from superficial and groundwater samples.

\section{Conflict of Interests}

The authors declare that there is no conflict of interests regarding the publication of this paper.

\section{Acknowledgments}

Financial support from the Universidad Nacional del Sur is gratefully acknowledged. M. A. Bavio is grateful to the Consejo Nacional de Investigaciones Científicas y Técnicas (CONICET).

\section{References}

[1] G. Concha, B. Nermell, and M. Vahter, "Metabolism of inorganic arsenic in children with chronic high arsenic exposure in northern Argentina," Environmental Health Perspectives, vol. 106, no. 6, pp. 355-359, 1998.

[2] J. O'Reilly, M. J. Watts, R. A. Shaw, A. L. Marcilla, and N. I. Ward, "Arsenic contamination of natural waters in San Juan and La Pampa, Argentina," Environmental Geochemistry and Health, vol. 32, no. 6, pp. 491-515, 2010.

[3] World Health Organization, Guidelines For Drinking-Water Qualityed, vol. 1, WHO Press, Geneva, Switzerland, 3th edition, 2008.

[4] K. Gupta and U. C. Ghosh, "Arsenic removal using hydrous nanostructure iron(III)-titanium(IV) binary mixed oxide from aqueous solution," Journal of Hazardous Materials, vol. 161, no. 2-3, pp. 884-892, 2009.

[5] B. Manna and U. C. Ghosh, "Pilot-scale performance of iron and arsenic removal from contaminated groundwater," Water Quality Research Journal of Canada, vol. 40, no. 1, pp. 82-90, 2005.

[6] D. Mohan and C. U. Pittman Jr., "Arsenic removal from water/wastewater using adsorbents-a critical review," Journal of Hazardous Materials, vol. 142, no. 1-2, pp. 1-53, 2007.

[7] S. Wang and C. N. Mulligan, "Natural attenuation processes for remediation of arsenic contaminated soils and groundwater," Journal of Hazardous Materials, vol. 138, no. 3, pp. 459-470, 2006.

[8] C. Luengo, V. Puccia, and M. Avena, "Arsenate adsorption and desorption kinetics on a Fe(III)-modified montmorillonite," Journal of Hazardous Materials, vol. 186, no. 2-3, pp. 1713-1719, 2011.

[9] M. L. Pierce and C. B. Moore, "Adsorption of arsenite and arsenate on amorphous iron hydroxide," Water Research, vol. 16, no. 7, pp. 1247-1253, 1982.

[10] T.-H. Hsia, S.-L. Lo, C.-F. Lin, and D.-Y. Lee, "Characterization of arsenate adsorption on hydrous iron oxide using chemical and physical methods," Colloids and Surfaces A, vol. 85, no. 1, pp. 1-7, 1994.

[11] J. A. Wilkie and J. G. Hering, "Adsorption of arsenic onto hydrous ferric oxide: effects of adsorbate/adsorbent ratios and co-occurring solutes," Colloids and Surfaces A, vol. 107, pp. 97110, 1996.

[12] W. Driehaus, M. Jekel, and U. Hildebrandt, "Granular ferric hydroxide-a new adsorbent for the removal of arsenic from natural water," Journal of Water Supply, vol. 47, no. 1, pp. 30-35, 1998.

[13] C. C. Fuller, J. A. Dadis, and G. A. Waychunas, "Surface chemistry of ferrihydrite: part 2. Kinetics of arsenate adsorption and coprecipitation," Geochimica et Cosmochimica Acta, vol. 57, no. 10, pp. 2271-2282, 1993.

[14] K. P. Raven, A. Jain, and R. H. Loeppert, "Arsenite and arsenate adsorption on ferrihydrite: kinetics, equilibrium, and adsorption envelopes," Environmental Science and Technology, vol. 32, no. 3, pp. 344-349, 1998.

[15] A. Jain and R. H. Loeppert, "Effect of competing anions on the adsorption of arsenate and arsenite by ferrihydrite," Journal of Environmental Quality, vol. 29, no. 5, pp. 1422-1430, 2000.

[16] Z. Sun, Z. Liu, Y. Wang, B. Han, J. Du, and J. Zhang, "Fabrication and characterization of magnetic carbon nanotube composites," Journal of Materials Chemistry, vol. 15, no. 42, pp. 4497-4501, 2005. 
[17] B. R. Manna, S. Dey, S. Debnath, and U. C. Ghosh, "Removal of arsenic from groundwater using crystalline hydrous ferric oxide (CHFO)," Water Quality Research Journal of Canada, vol. 38, no. 1, pp. 193-210, 2003.

[18] R. R. Frost and R. A. Griffin, "Effect of pH on adsorption of arsenic and selenium fromlandfill leachate by clay minerals," Soil Science Society of America Journal, vol. 41, no. 1, pp. 53-57, 1977.

[19] Z. Li, R. Beachner, Z. McManama, and H. Hanlie, "Sorption of arsenic by surfactant-modified zeolite and kaolinite," Microporous and Mesoporous Materials, vol. 105, no. 3, pp. 291-297, 2007.

[20] A. Saada, D. Breeze, C. Crouzet, S. Cornu, and P. Baranger, "Adsorption of arsenic (V) on kaolinite and on kaolinitehumic acid complexes role of humic acid nitrogen groups," Chemosphere, vol. 51, no. 8, pp. 757-763, 2003.

[21] Z. Deng, E. Yenilmez, J. Leu et al., "Metal-coated carbon nanotube tips for magnetic force microscopy," Applied Physics Letters, vol. 85, no. 25, pp. 6263-6265, 2004.

[22] S. Utsumi, K. Urita, H. Kanoh et al., "Preparing a magnetically responsive single-wall carbon nanohorn colloid by anchoring magnetite nanoparticles," Journal of Physical Chemistry B, vol. 110, no. 14, pp. 7165-7170, 2006.

[23] P. Xu, D. Cui, B. Pan et al., "A facile strategy for covalent binding of nanoparticles onto carbon nanotubes," Applied Surface Science, vol. 254, no. 16, pp. 5236-5240, 2008.

[24] F. Stoffelbach, A. Aqil, C. Jérôme, R. Jérôme, and C. Detrembleur, "An easy and economically viable route for the decoration of carbon nanotubes by magnetite nanoparticles, and their orientation in a magnetic field," Chemical Communications, no. 36, pp. 4532-4533, 2005.

[25] G. Morales-Cid, A. Fekete, B. M. Simonet et al., "In situ synthesis of magnetic multiwalled carbon nanotube composites for the clean-up of (Fluoro)Quinolones from human plasma prior to ultrahigh pressure liquid chromatography analysis," Analytical Chemistry, vol. 82, no. 7, pp. 2743-2752, 2010.

[26] M. A. Correa-Duarte, M. Grzelczak, V. Salgueiriño-Maceira et al., "Alignment of carbon nanotubes under low magnetic fields through attachment of magnetic nanoparticles," Journal of Physical Chemistry B, vol. 109, no. 41, pp. 19060-19063, 2005.

[27] W. Li, C. Gao, H. Qian, J. Ren, and D. Yan, "Multiaminofunctionalized carbon nanotubes and their applications in loading quantum dots and magnetic nanoparticles," Journal of Materials Chemistry, vol. 16, no. 19, pp. 1852-1859, 2006.

[28] V. Georgakilas, V. Tzitzios, D. Gournis, and D. Petridis, "Attachment of magnetic nanoparticles on carbon nanotubes and their soluble derivatives," Chemistry of Materials, vol. 17, no. 7, pp. 1613-1617, 2005.

[29] F. Tan, X. Fan, G. Zhang, and F. Zhang, "Coating and filling of carbon nanotubes with homogeneous magnetic nanoparticles," Materials Letters, vol. 61, no. 8-9, pp. 1805-1808, 2007.

[30] L. Kong, X. Lu, and W. Zhang, "Facile synthesis of multifunctional multiwalled carbon nanotubes $/ \mathrm{Fe}_{3} \mathrm{O}_{4}$ nanoparticles/polyaniline composite nanotubes," Journal of Solid State Chemistry, vol. 181, no. 3, pp. 628-636, 2008.

[31] C. Huiqun, Z. Meifang, and L. Yaogang, "Novel carbon nanotube iron oxide magnetic nanocomposites," Journal of Magnetism and Magnetic Materials, vol. 305, no. 2, pp. 321-324, 2006.

[32] J. Wan, W. Cai, J. Feng, X. Meng, and E. Liu, "In situ decoration of carbon nanotubes with nearly monodisperse magnetite nanoparticles in liquid polyols," Journal of Materials Chemistry, vol. 17, no. 12, pp. 1188-1192, 2007.
[33] B. Jia and L. Gao, "Fabrication of "tadpole"-like magnetite/ multiwalled carbon nanotube heterojunctions and their selfassembly under external magnetic field," Journal of Physical Chemistry B, vol. 111, no. 19, pp. 5337-5343, 2007.

[34] S. Tsang, F. Phu, M. M. Baum, and G. A. Poskrebyshev, "Determination of phosphate/arsenate by a modified molybdenum blue method and reduction of arsenate by $\mathrm{S}_{2} \mathrm{O}_{4}^{-2}$," Talanta, vol. 71, no. 4, pp. 1560-1568, 2007.

[35] M. I. Kandah and J.-L. Meunier, "Removal of nickel ions from water by multi-walled carbon nanotubes," Journal of Hazardous Materials, vol. 146, no. 1-2, pp. 283-288, 2007.

[36] Y.-H. Li, S. Wang, Z. Luan, J. Ding, C. Xu, and D. Wu, "Adsorption of cadmium(II) from aqueous solution by surface oxidized carbon nanotubes," Carbon, vol. 41, no. 5, pp. 1057-1062, 2003.

[37] C. Lu, Y.-L. Chung, and K.-F. Chang, "Adsorption of trihalomethanes from water with carbon nanotubes," Water Research, vol. 39, no. 6, pp. 1183-1189, 2005.

[38] C. Lu and H. Chiu, "Chemical modification of multiwalled carbon nanotubes for sorption of $\mathrm{Zn}^{2+}$ from aqueous solution," Chemical Engineering Journal, vol. 139, no. 3, pp. 462-468, 2008.

[39] Y. Zhan, R. Zhao, Y. Lei, F. Meng, J. Zhong, and X. Liu, "A novel carbon nanotubes $/ \mathrm{Fe}_{3} \mathrm{O}_{4}$ inorganic hybrid material: Synthesis, characterization and microwave electromagnetic properties," Journal of Magnetism and Magnetic Materials, vol. 323, no. 7, pp. 1006-1010, 2011.

[40] S.-C. Chang, T. I. Anderson, S. E. Bahrman, C. L. Gruden, A. I. Khijniak, and P. Adriaens, "Comparing recovering efficiency of immunomagnetic separation and centrifugation of mycobacteria in metalworking fluids," Journal of Industrial Microbiology and Biotechnology, vol. 32, no. 11-12, pp. 629-638, 2005.

[41] U. Schwertmann, "The double dehydroxylation peak of goethite," Thermochimica Acta, vol. 78, no. 1-3, pp. 39-46, 1984.

[42] M. Erdemoğlu and M. Sarikaya, "Effects of heavy metals and oxalate on the zeta potential of magnetite," Journal of Colloid and Interface Science, vol. 300, no. 2, pp. 795-804, 2006.

[43] A. L. Ulery and L. R. Drees, Methods of Soil Analysis. Part 5, Mineral. Methods, Soil Science Society of America, Wisconsin, Madison, Wis, USA, 2008.

[44] P. H. Hsu, "Determination of iron with thiocyanate," Soil Science Society of America Journal, vol. 31, no. 3, pp. 353-355, 1967.

[45] A. E. Regazzoni, M. A. Blesa, and A. J. G. Maroto, "Interfacial properties of zirconium dioxide and magnetite in water," Journal of Colloid And Interface Science, vol. 91, no. 2, pp. 560-570, 1983.

[46] M. Pigna, G. S. R. Krishnamurti, and A. Violante, "Kinetics of arsenate sorption-desorption from metal oxides: effect of residence time," Soil Science Society of America Journal, vol. 70, no. 6, pp. 2017-2027, 2006.

[47] T. Tuutijärvi, J. Lu, M. Sillanpää, and G. Chen, "As(V) adsorption on maghemite nanoparticles," Journal of Hazardous Materials, vol. 166, no. 2-3, pp. 1415-1420, 2009.

[48] P. Chutia, S. Kato, T. Kojima, and S. Satokawa, "Arsenic adsorption from aqueous solution on synthetic zeolites," Journal of Hazardous Materials, vol. 162, no. 1, pp. 440-447, 2009.

[49] A. Vaseashta, M. Vaclavikova, S. Vaseashta, G. Gallios, P. Roy, and O. Pummakarnchana, "Nanostructures in environmental pollution detection, monitoring, and remediation," Science and Technology of Advanced Materials, vol. 8, no. 1-2, pp. 47-59, 2007.

[50] P. H. Masscheleyn, R. D. Delaune, and W. H. Patrick Jr., "Effect of redox potential and $\mathrm{pH}$ on arsenic speciation and solubility in a contaminated soil," Environmental Science and Technology, vol. 25, no. 8, pp. 1414-1419, 1991. 

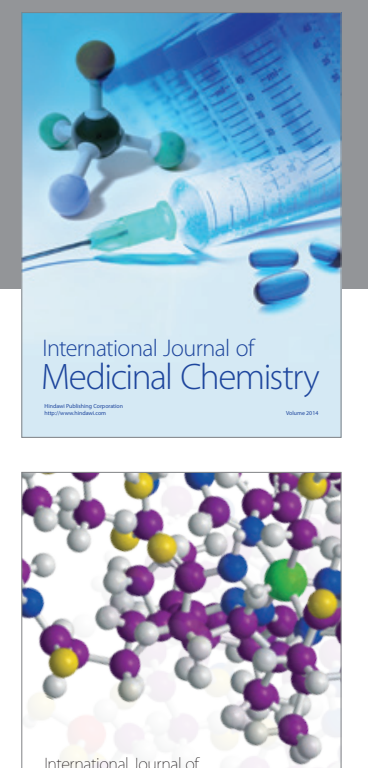

\section{Carbohydrate} Chemistry

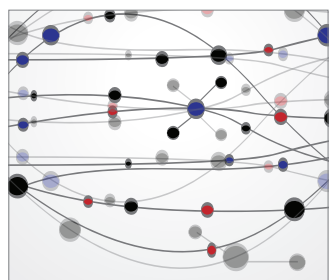

The Scientific World Journal
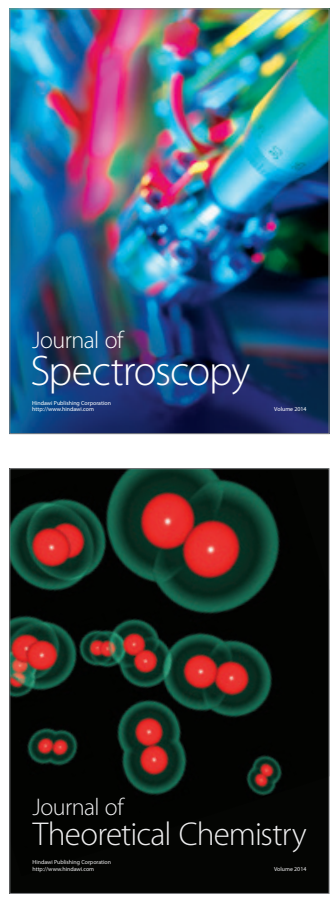
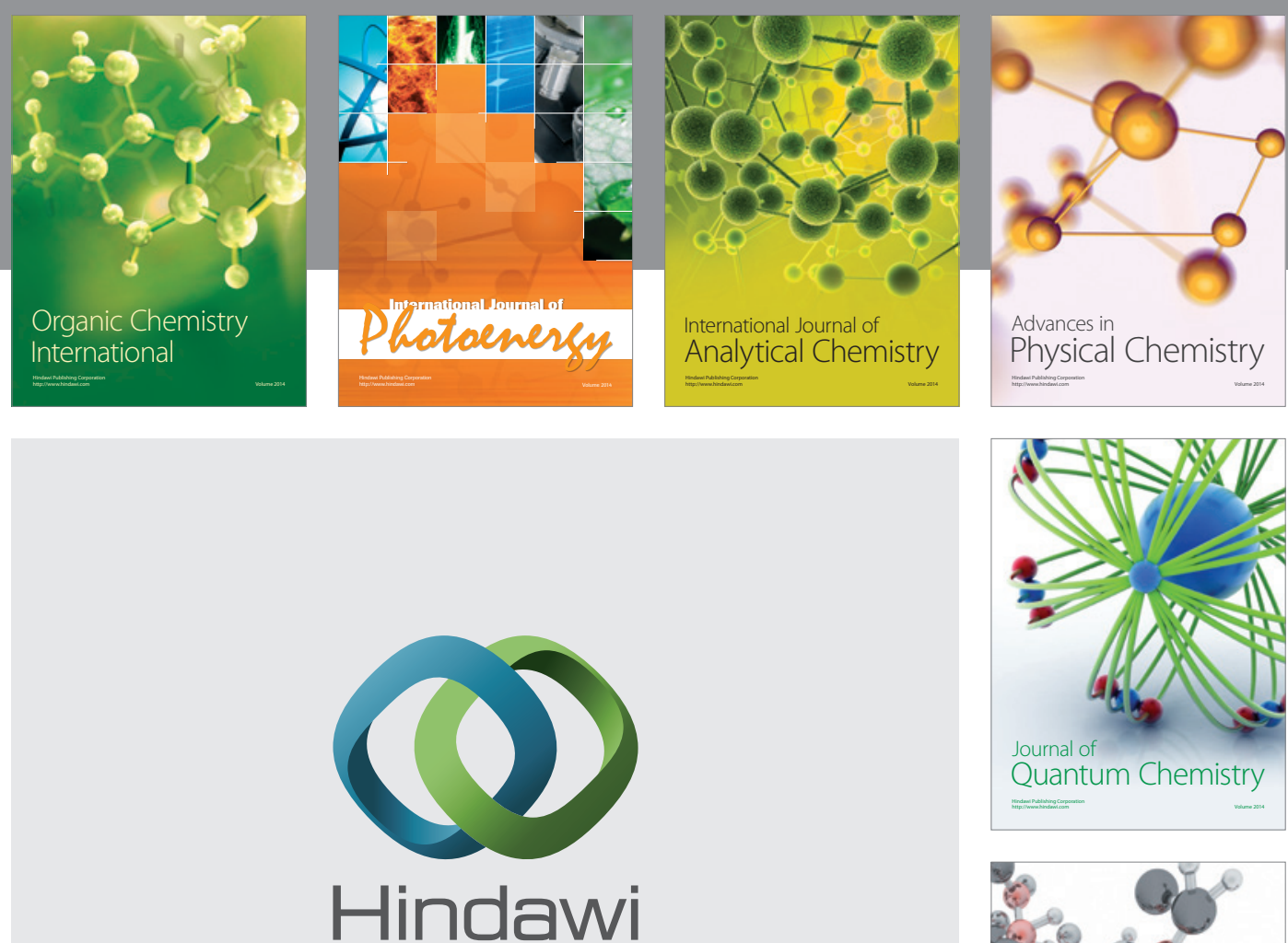

Submit your manuscripts at

http://www.hindawi.com

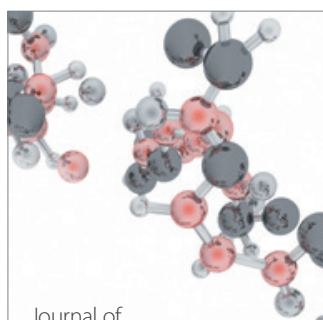

Analytical Methods

in Chemistry

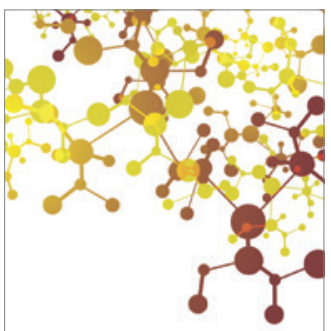

Journal of

Applied Chemistry

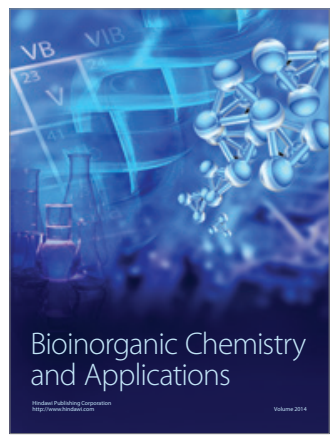

Inorganic Chemistry
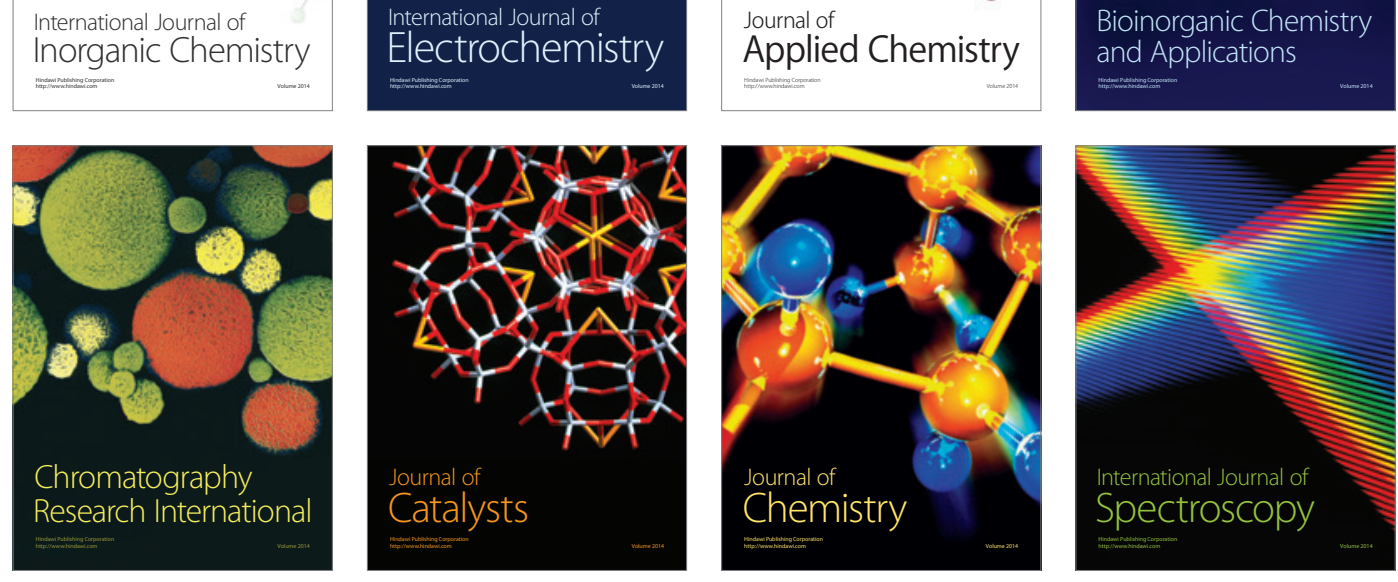